\title{
Hugo Chávez dan Kebangkitan Populisme-Kiri Amerika Latin: Venezuela Era Hugo Chávez (1998-2006)
}

\author{
Daniel Hutagalung \\ Peneliti Center for Terrorism and Social Conflict Studies, alumnus UI dan University of Birmingham, \\ Inggris
}

\begin{abstract}
Hugo Chávez appeared and emerged in Venezuela under political-economic crisis. This article argues that his power struggle supported by the people because Chavez vision and mission are to favour the people inrerest, and he takes care about people. . Chave political project, as stated Ellner as non- revolutionary path of radical populism, expressed through various political program missions, namely to encourage social revolutionary program, but not in the political project of the revolution, at least during the Chávez powers throughout 19982006. However, Ellner mentioned that non- revolutionary path of radical populism can also lead to revolutionary-path, meaning that political poryek Chávez is still unfinished and still possible to reach a variety of changes, whether the "Bolivarian Revolution" will take the form of non-revolutionary transformation, or even revolutionary- path.
\end{abstract}

Kata Kunci: crisis; populism;revolution; Hugo Chávez; capitalism

\section{Pendahuluan}

Selasa 5 Maret 2013, Hugo Rafael Chávez Frías, Presiden Republik Bolivarian Venezuela, meninggal dunia di rumah sakit militer di Caracas, Venezuela, akibat penyakit kanker. Hugo Chávez muncul sebagai tokoh kontroversial yang memukau. Dicintai rakyat miskin Venezuela, sekaligus dimusuhi oleh banyak kalangan elit kaya, kaum berada dan jenderaljenderal militer yang disokong pemerintah Amerika Serikat (AS). Chávez membangun politik luar negeri yang sangat anti AS. Permusuhan kepada pemerintah AS ia pertunjukkan bukan hanya dalam pidato-pidato di televisi, wawancara di media massa, melainkan juga dalam kesempatan resmi, seperti misalnya pada pidato di Sidang Umum Perserikatan Bangsa-Bangsa (PBB). Dalam Sidang Umum PBB tahun 2006, Chávez menyebut pemerintah AS sebagai setan atau "devil". Secara gamblang dan terang-terangan, Chávez mengungkapkannya dalam frasa berikut:

The devil came here yesterday. Yesterday, the Devil was here in this very place. This rostrum still smells like sulfur. Yesterday, ladies and gentlemen, from this podium, the President of the United States, whom I refer to as the Devil, came here talking as if he owned the world. It would take a psychiatrist to analyze the speech he delivered 
Konfrontasi: Jurnal Kultur, Ekonomi dan Perubahan Sosial, 1 (2) Juli 2014, 56-73

P-ISSN: 1410-881X (Print)

Daniel Hutagalung, Hugo Chávez dan Kebangkitan Populisme-Kiri Amerika Latin: Venezuela Era Hugo Chávez (1998-2006)

DOI: -

http://www.konfrontasi.net/index.php/konfrontasi2

yesterday. As the spokesperson for imperialism, he came to give us his recipes for maintaining the current scheme of domination, exploitation dan pillage over the peoples of the world. ${ }^{1}$

Hugo Chávez menjadi ikon penting bukan saja bagi Venezuela, melainkan juga bagi seluruh benua Amerika Selatan. Ia juga menjadi simbol perlawanan terhadap dominasi AS dan sistem kapitalisme, bagi banyak negara dan kelompok-kelompok perlawanan di seluruh belahan dunia. Namanya menjadi kontroversi, dipuja sekaligus dibenci. Banyak juga yang menilai Chávez merupakan penyeimbang baru kutub politik dunia setelah runtuhnya Uni Soviet, dan kekuatan dunia menjadi semakin unipolar di bawah AS dan sekutu-sekutunya di Eropa Barat. Kalau merujuk pada obituari yang ditulis harian The Guardian, secara internasional Chávez mengambol posisi sebagai anti-imperialis dan banyak mencurahkan bantuan kepada sekutu ideo- logisnya. Menurut Chávez, Venezuela akan memainkan peran vital dalam upaya menyelematkan bumi dari iblis kapitalisme, sebagaimana ia ucapkan dalam pidato di atas. ${ }^{2}$ Pengaruh Chávez yang bertambah luas, mendorong terjadinya perubahan besar di kawasan Amerika Latin, pasca kemenangannya dalam pemilihan presiden pada 1998.

Dalam kurun waktu limabelas tahun terakhir, wilayah Amerika Selatan seketika menjadi "wilayah merah" di mana sebagian besar negara-negara di wilayah itu dikuasai oleh pemerintahan-pemerintahan yang berhaluan sosialis, atau setidaknya mendapatkan dukungan dari kalangan sosialis, yang berorientasi pada kebijakan populis, berlawanan dengan rezimrezim sebelumnya yang kebanyakan dipimpin pemerintahan militer yang totaliter, atau rezim boneka Amerika Serikat (AS). Kebangkitan kekuatan populis berhaluan Kiri di wilayah ini tidak bisa dilepaskan dari munculnya sosok kontroversial, yakni Hugo Chávez Frías, seorang berlatar belakang militer berpangkat terakhir letnan kolonel, yang memenangkan pemilihan umum di Venezuela pada tahun 1998, yang kemudian dinilai memberikan inspirasi dan dorongan di sejumlah negara lain di tahun-tahun berikutnya.

Tulisan ini lebih merupakan pandangan umum mengenai kebangkitan apa yang disebut gerakan populisme di Amerika Latin, dengan secara khusus melihatnya melalui kasus kemenangan Hugo Chávez dalam pemilu Venezuela dan gambaran umum mengenai pemerintahan periode pertama Chávez dari tahun 1998-2006. Untuk itu tulisan ini lebih bertujuan untuk mendeskripsi- kan sekaligus menganalisis pergeseran dari apa yang diistilahkan Steve Ellner sebagai revolutionary path menjadi non-revolutionary path of radical populism sebagaimana terjadi di Venezuela secara khusus, dan juga berbagai kemenangan kelompok populis-kiri di sejumlah negara Amerika Latin melalui jalur elektoral.4 Jalur kedua, yakni nonrevolutionary path, atau dalam istilah Steve Ellner sebagai non-

\footnotetext{
${ }^{1}$ Hugo Chávez Frías, "Statement by H. E. Hugo Chávez Frías, President of the Bolivarian Republic of Venezuela at the 61st United Nations General Assembly", New York, September 20th, 2006, dalam Law and Business Review of the Americas, 12 (4) (Fall 2006), hal. 431.

${ }^{2}$ Phil Gunson, "Hugo Chávez Obituary", The Guardian, 5 March 2013.
} 
Konfrontasi: Jurnal Kultur, Ekonomi dan Perubahan Sosial, 1 (2) Juli 2014, 56-73

P-ISSN: 1410-881X (Print)

Daniel Hutagalung, Hugo Chávez dan Kebangkitan Populisme-Kiri Amerika Latin: Venezuela Era Hugo Chávez (1998-2006)

DOI: -

http://www.konfrontasi.net/index.php/konfrontasi2

revolutionary transformation, merupakan suatu gerakan yang dibangun dengan menciptakan partai berbasis massa, institusi- institusi demokratis dan gaya politik yang kerap disebut dengan "politics of the masses". Ellner melihat Venezuela di bawah Chávez dalam hal bagaimana menerapkan revolutionary opportunity dan pendekatan non-revolutionary transformation dalam debat politik dan pertarungan politik yang membentuk suatu identitas politik, yakni Chavista, atau para pendukung Chávez. ${ }^{3}$

\section{Terpaan Gelombang Populis-Kiri di Amerika Latin}

Kalau mengikuti frasa terkenal dari Karl Marx, "Ada hantu yang sedang bergentayangan di Amerika Latin - hantu "Populisme". Frasa tersebut cocok dilekatkan pada munculnya gelombang para pemimpin kiri-populis radikal di Amerika Latin, di antaranya Hugo Chávez di Venezuela, Evo Morales di Bolivia dan Rafael Correa di Ekuador. Apa yang berkembang di benua Amerika Selatan banyak dirujuk sebagai sebuah gejala kebangkitan gerakan populisme-kiri. Model gerakan populis yang demikian tersohor semenjak kemunculan Juan Perón di Argentina pada 1945. Jenderal Juan Perón, tokoh populis yang mendapatkan dukungan luas dari masyarakat Argentina waktu itu, menumbuhkan gerakan yang mengental menjadi apa yang kemudian dikenal dengan gerakan Peronism. ${ }^{4}$

Dalam hal ini maka menjadi penting untuk mendiskusikan populisme sebagai sebuah konsep politik. Meski populisme sebagai konsep tidak mengandung definisi tunggal, namun pada umumnya dalam pemahaman sehari-hari, populisme merupakan istilah yang disalahgunakan, pertanda sebuah penyakit yang berbahaya bagi tubuh kepolitikan. Para pemimpin populis kerap dikatakan para demagog otoriter yang menghasut emosi para pemilik hak suara dalam pemilu untuk dapat memperoleh dukungan mereka, mengajak berprasangka dan mendendam dalam mempengaruhi para pemilih untuk menentang tatatan politik yang ada. Para populis dianggap hanya memiliki secuil respek terhadap institusi-institusi dan prosedur demokrasi; mereka mengatakan apa yang ingin didengar orang banyak tanpa mempertimbangkan konsekuensi jangka panjang dalam bidang ekonomi dan politik.7

Meski demikian, cara pandang di atas sudah banyak mendapatkan kritik, tentangan dan sanggahan. Kalau merujuk pada argumen yang diajukan Francisco Panizza, ada kondisi- kondisi bagi kemunculan populisme, di mana populisme muncul bukan semata-mata dikarenakan terjadinya krisis representasi di mana rakyat yang menanggalkan identitas lama mereka dan memeluk identitas "populer" yang baru, melainkan juga merupakan awal dari representasi, dan memungkinkan orang-orang yang sebelumnya tidak pernah terwakilkan,

\footnotetext{
${ }_{3}^{3}$ Ibid., hal.163. Untuk keperluan itu Ellner melakukan wawancara dengan 38 pimpinan Chavista dari seluruh tingkatan/level.

${ }^{4}$ Pada 17 Oktober 1945, lautan massa berkumpul di alun-alun Buenos Aires, ibukota
} 
Konfrontasi: Jurnal Kultur, Ekonomi dan Perubahan Sosial, 1 (2) Juli 2014, 56-73

P-ISSN: 1410-881X (Print)

Daniel Hutagalung, Hugo Chávez dan Kebangkitan Populisme-Kiri Amerika Latin: Venezuela Era Hugo Chávez (1998-2006)

DOI: -

http://www.konfrontasi.net/index.php/konfrontasi2

disebabkan karena kelas sosial, agama, etnisitas atau lokasi geografis, kemudian dikenal dan diakui sebagai aktor politik. ${ }^{5}$

Panizza kemudian menguraikan kondisi-kondisi yang memungkinkan bagi munculnya populisme, yakni: Pertama, kekacauan tatanan sosial dan hilangnya kepercayaan terhadap kemampuan sistem politik untuk memperbaiki kekacauan tersebut. Yang khas dari situasi ini adalah krisis ekonomi termanisfestasi di dalam fenomena seperti hiper-inflasi, dan krisis ekonomi selalu lebih dari sekedar ekonomi. Kedua, tradisi politik yang

Argentina, di depan Kantor Kepresidenan (House of Government). Mereka menuntut dibebaskannya seorang laki-laki yang ditahan beberapa hari sebelumnya. Sebagian besar lakilaki dan perempuan yang berkumpul dan menyuarakan tuntutan tersebut adalah kaum buruh. Laki-laki yang ditahan tersebut adalah Juan Perón. Pada hari itu, lahirlah apa yang dinamakan gerakan politik populis, yang kemudian hari dikenal dengan sebutan Peronism. Uraian ringkas mengenai Peronism yang dirujuk pada tulisan ini adalah karya Sebastian Barros and Gustavo Castagnola, "The Political Frontiers of the Social: Argentine Politics After Peronist Populism (1955-1973)" dalam David Howarth, Aletta J. Norval and Yannis Stavrakakis (Eds), Discourse Theory and Political Analysis: Identities, Hegemonies and Social Changes (Manchester: Manchester University Press), hal. 24-37 melelahkan dan membosankan dan orang-orang kehilangan kepercayaan terhadap partai-partai politik. Tuduhan terhadap korupsi, malpraktik, serta kontrol kehidupan publik oleh elit politik yang dianggap tidak layak dan hanya memikirkan kepentingan dirinya sendiri merupakan situasi tipikal di mana populisme mengambil bentuk "politik dari anti-politik", kerena politisi dan partai politik menjadi "yang lain" (the other) dari rakyat. Dalam situasi ini, ideologi politik tradisional, baik Kiri maupun Kanan kehilangan kekuatan mereka untuk mengorganisir diskursus politik, dan partai-partai yang telah lama berkuasa akan tersapu dari kekuasaan. Ketiga, terjadinya perubahan di tingkat ekonomi, budaya, dan kemasyarakatan, seperti proses urbanisasi dan modernisasi ekonomio, mengubah keseimbangan demografis antara kelas sosial, dan antara kelompok regional dan etnis, dan paling kini adalah globalisasi. Kekacauan sosial dan mobilitas sosial mengubah identitas yang mapan, kehilangan relasi subordinasi yang tradisional dan membuka bentukbentuk baru identifikasi, seperti kelas buruh baru yang terdiri dari para migran dari pedesaan yang menjadi basis sosial Peronisme di era 1940AN. Keempat, politik populis selalu berkaitan erat dengan munculnya bentuk representasi politik di luar institusi-institusi politik tradisional.9 Dengan empat kondisi tersebut, kemunculan populisme di Amerika Latin belakangan ini bisa dilacak dan diuraikan. Di mana kondisi-kondisi yang diuraikan Panizza, cukup membantu menganalisa pola kebangkitan populisme di berbagai negara Amerika Latin, khususnya Venezuela yang menjadi fokus tulisan ini.

\footnotetext{
${ }^{5}$ Francisco Panizza, "Populism and the Mirror of Democracy" dalam Francisco Panizza (Ed), Populism and the Mirror of Democracy (London: Verso, 2005), hal. 11.
} 
Konfrontasi: Jurnal Kultur, Ekonomi dan Perubahan Sosial, 1 (2) Juli 2014, 56-73

P-ISSN: 1410-881X (Print)

Daniel Hutagalung, Hugo Chávez dan Kebangkitan Populisme-Kiri Amerika Latin: Venezuela Era Hugo Chávez (1998-2006)

DOI: -

http://www.konfrontasi.net/index.php/konfrontasi2

Kemenangan Hugo Chávez Frías dalam pemilihan umum Venezuela tahun 1998 dipandang sebagai faktor penting dari kebangkitan gerakan populis-kiri di Amerika Latin. Setelah Chávez memenangkan pemilu Venezuela, Luis Ignácio "Lula" da Silva pimpinan Partai Buruh (Partido dos Trabalhadores) Brasil yang berorientasi kiri juga memenangkan pemilu Brasil pada 2002, lalu Evo Morales di Bolivia pada tahun 2002, Lucio Gutiérrez di Ekuador pada 2003, Néstor Kirchner di Argentina pada 2003, Tabaré Vázquez di Uruguay pada 2004, Michelle Bachelet di Chili pada 2006, Rafael Correa di Ekuador pada 2006 dan Fernando Lugo di Paraguay pada 2008. Rezim-rezim baru ini membawa isu sosialisme sebagai agenda perjuangan politik mereka, dengan mengatasnamakan kaum miskin, penduduk asli, dan rakyat yang ditindas dan dihisap. Keberhasilan Lucio Gutiérrez menduduki tampuk kekuasaan, banyak dipandang sebagai kemajuan politik yang besar bagi warga penduduk asli (indigenous nationalities) yang selama lima ratus tahun telah memperjuang- kan isu-isu kebebasan (dari penindasan dan penghisapan) dan demokrasi (partisipasi langsung dalam penentuan kebijakan nasional dari urusan politik negara). Demikian juga di Bolivia, di mana Evo Morales, pemimpin organisasi Cocaleros, yakni organisasi petani coca (bahan dasar opium), yang berhasil memenangi pemilu pada 2002.10

Keberhasilan rezim-rezim baru menguasai sejumlah negara di Amerika Latin menandai babak baru dalam polarisasi kekuatan politik global, di mana rezim-rezim yang pro- Amerika atau didukung Amerika Serikat dikalahkan oleh rezim-rezim baru neo- populis, yang mengedepanakn isu-isu seperti sosialisme, hak-hak adat, penghormatan etnis, dan juga kaum perempuan. Rezim baru neo-populis ini berbeda dari rezim-rezim populis klasik yang kemudian jatuh menjadi totaliter bahkan fasis. Meskipun tidak semua rezim bisa dikatakan seragam, di mana misalnya Lula dan Bachelet, masih menerima sistem ekonomi pasar, sementara Castro, Chávez dan Morales menolak keras ekonomi pasar, dan menghadapinya dengan program nasionalisasi terhadap berbagai sektor usaha privat, namun secara keseluruhan, rezim-rezim populis tersebut memiliki kekentalan dengan semangat Kiri, yakni berbicara mengenai keadilan sosial, kesejahteraan bersama dan kesetaraan.

\section{Chávez dan Kepolitikan Baru Venezuela}

Kemenangan telak Chávez dalam pemilu presiden pada 1998 bisa menjadi bukti yang paling jelas saat ini mengenai kekuatan populisme dalam politik kontemporer Amerika Latin, meskipun dalam tradisi kepolitikan di Amerika Latin, populisme bukanlah sesuatu hal yang baru. Sebagaimana disebut pada bagian awal tulisan, di era 1940AN, Juan Perón muncul sebagai pemimpin gerakan populis di Argentina, bahkan menjadi identitas politik bagi pengikutnya, yakni Peronism. Rangkaian gejolak politik dan kudeta militer banyak mewarnai Amerika Latin sepanjang tahun 1940AN sampai 1970AN, termasuk yang dialami Juan Perón saat digulingkan dan dibuang pada 1955. Figur- 
Konfrontasi: Jurnal Kultur, Ekonomi dan Perubahan Sosial, 1 (2) Juli 2014, 56-73

P-ISSN: 1410-881X (Print)

Daniel Hutagalung, Hugo Chávez dan Kebangkitan Populisme-Kiri Amerika Latin: Venezuela Era Hugo Chávez (1998-2006)

DOI: -

http://www.konfrontasi.net/index.php/konfrontasi2

figur populis lainnya juga banyak bermunculan seperti Getúlio Vargas (Brasil), Lázaro Cárdenas (Meksiko) dan Victor Raúl Haya de la Torre (Peru), juga partai-partai populis yang memperjuangkan organisasi-organisasi akar- rumput, reformasi sosial dan nasionalisasi industri subtitusi impor.

Venezuela sendiri mengalami pergolakan di tahun 1950AN, di mana rezim militer yang berkuasa dijatuhkan oleh aliansi kekuatan sipil bersama sejumlah faksi di dalam militer. Kalau melihat lebih ke belakang, pada 1948 faksi militer di bawah pimpinan Jenderal Carlos Delgado Chalbaud, yang dipandang relatif progresif, mengambil alih kekuasaan di Venezuela. Namun, pada tahun 1950 Jenderal Chalbaud dibunuh, dan kekuasaan diambil alih oleh Jenderal Marcos Pérez Jiménez, yang kemudian memerintah secara otoriter, dengan menekan partai-partai politik, serikat-serikat buruh, dan memaksakan pemberlakuan sensor terhadap media massa. Jenderal Pérez Jiménez banyak dinilai sebagai seorang nasionalis, yang selalu mempromosikan industri nasional dan infrastruktur, dan terus mengupayakan ukuran-ukuran kesejahteraan, dan karena hal-hal itu ia banyak dikenang oleh sejumlah sektor masyarakat dalam kelas-kelas sosial, jika dibandingkan dengan para "demokrat" korup yang berkuasa kemudian, meski di bawah kekuasaan Jiménez, tindakan represif dan korupsi juga berlangsung.

Meskipun demikian, ketidakpuasan terhadap kepemimpinan Pérez Jiménez meluas di seantero Venezuela, karena kepemimpinannya yang represif dan korup, yang mendorong pembentukan gerakan bawah-tanah Junta Patriótica untuk menjatuhkan Pérez Jiménez, yang di dalamnya termasuk partai-partai seperti: Acción Democrática (AD), Comité de Organización Politica Electoral Independiente (COPEI), Unión Republicana Democrática (URD), dan Partido Comunista Venezolano (PCV) yang mendapat dukungan dari salah satu faksi di dalam tubuh militer, melancarkan sebuah pemberontakan aliansi sipil-militer yang berhasil memperoleh kemenangan besar dengan menjatuhkan pemerintahan Jenderal Pérez Jiménez pada 23 Januari 1958.13

Pemberontakan ini banyak diakui sebagai sebuah kemenangan revolusi demokratik populer, dan pada bulan-bulan berikutnya atmosfer sosial Venezuela sudah mendekati suasana seperti revolusi. Namun, pada 31 Oktober 1958, tiga partai besar yakni AD, COPEI dan URD, menandatangani sebuah perjanjian yang disebut Pakta Punto Fijo, yakni perjanjian formal untuk melakukan pembagian kekuasaan dan kontrol pemerintahan serta menjamin keberlangsungan "stabilitas" politik. Pakta ini sekaligus juga merupakan titik-balik untuk menyingkirkan PCV, yang berhaluan komunis, dari arena kekuasaan. Pakta ini kemudian dikenal dengan sebutan puntofujismo, yang dilambangkan dengan upaya menetralisir gairah revolusi populis yang sempat muncul setelah peristiwa 23 Januari 1958.14 Di bawah Pakta Punto Fijo, para pemimpin kedua partai utama, yakni AD dan COPEI, menyusun sebuah agenda kebijakan sebelum pelaksanaan pemilu, dan sepakat untuk membagi jabatan dalam kabinet dan 
Konfrontasi: Jurnal Kultur, Ekonomi dan Perubahan Sosial, 1 (2) Juli 2014, 56-73

P-ISSN: 1410-881X (Print)

Daniel Hutagalung, Hugo Chávez dan Kebangkitan Populisme-Kiri Amerika Latin: Venezuela Era Hugo Chávez (1998-2006)

DOI: -

http://www.konfrontasi.net/index.php/konfrontasi2

posisi pemerintahan lainnya di antara partai-partai utama setelah pemilu yang memilih kandidat mana yang memenangi penghitungan suara.15

Rómulo Betancourt dari AD terpilih untuk membentuk pemerintahan dan mendefinisikan pemerintahannya sebagai "persatuan nasional", bersama- sama perwakilan COPEI dan URD. Dalam pidato pelantikan presiden yang disampaikan pada 13 Februari 1959, Betancourt mendeklarasikan bahwa "the philosophy of Communism is not compatible with the development of Venezuela".16 Dengan itu pemerintahan AD, COPEI dan URD secara tegas menyingkirkan PCV dari koalisi pemerintahan, meskipun sebelumnya mereka bersamasama PCV menumbangkan rejim militer Jenderal Pérez Jiménez.

Semenjak pemberontakan 1958, Venezuela dipimpin oleh pemerintahan sipil yang berjangkar pada dua partai politik dominan yakni AD dan COPEI yang kerap menang lewat jalan pemilu secara stabil, memiliki displin internal partai yang kuat dan mengakar di dalam masyarakat sipil. AD dan COPEI merupakan partai yang tersuktrur secara birokratis dan hirarkis, dan memiliki peralatan politik yang mampu melakukan penetrasi ke setiap sudut dan celah masyarakat Venezuela, membangkitkan loyalitas politik yang sangat kuat, dan identitas kolektif yang kohesif.17 Dalam kebijakannya, kedua partai tersebut hampir tidak memiliki perbedaan pokok antara satu dengan lainnya. Ini dikarenakan Pakta Punto Fijo yang ditandangani para pimpinan politik kedua partai di tahun 1958.

Perjanjian berdasarkan Pakta Punto Fijo perlahan-lahan mulai retak terutama karena beberapa hal, di antaranya: Pertama, pengelolaan politik berdasarkan patronase terus meningkat, karena tidak ada satupun partai yang mampu melakukan kontrol terhadap pengeluaran negara yang sangat besar selama berkuasa. Lembaga-lembaga politik yang berkuasa merupakan persekutuan dari pengusaha (corporatist) dan hubungan clientelist kepada aktor-aktor sosial dan politik. Model pengelolaan semacam ini menghasilkan korupsi dan pembelanjaan negara yang sangat tinggi, yang mendorong kemerosotan perekonomian. Sistem kepartaian Punto Fijo mendorong patronase selektif dalam hal akses ekonomi, dan mendorong korupsi politik. Dalam survei opini publik menunjukkan turunnya kepercayaan publik pada sistem kepartaian dan partai Punto Fijo (AD dan COPEI), dan warga Venezuela menyalahkan kemapanan politik dan korupsi yang menyebar luas sebagai biang kerok terjadinya krisis ekonomi di negara yang kaya minyak.

Kedua, adanya tekanan politik yang kuat yang datang dari kelompok- kelompok PCV yang disingkirkan dari arena politik nasional melalui Pakta Punto Fijo, dan mengorganisir perlawanan melalui protes besar-besaran. Dalam menanggapi ini pemerintah berkuasa pada 1960An melakukan penekanan terhadap protes rakyat dan kelompok-kelompok Kiri dengan tangan besi: pada Agustus 1969 demonstrasi mahasiswa dan buruh dihadapi dengan tembakan oleh aparat kepolisian, yang menyebabkan jatuhnya korban jiwa di kalangan demonstran.19 Tindakan tersebut memprovokasi perpecahan serius di dalam tubuh Partai AD, yang puncaknya pada bulan Maret dan Juli 1960, seluruh sayap 
Konfrontasi: Jurnal Kultur, Ekonomi dan Perubahan Sosial, 1 (2) Juli 2014, 56-73

P-ISSN: 1410-881X (Print)

Daniel Hutagalung, Hugo Chávez dan Kebangkitan Populisme-Kiri Amerika Latin: Venezuela Era Hugo Chávez (1998-2006)

DOI: -

http://www.konfrontasi.net/index.php/konfrontasi2

pemuda dalam AD keluar dari partai dan membentuk partai baru yakni Movimiento de la Izquierda Revolucionaria (MIR) atau Movement of the Revolutionary Left. Berlanjutnya protes dan tekanan dari pemerintah terhadap gerakan mahasiswa dan buruh, mendorong URD keluar dari pemerintahan, dan akhirnya puntofijismo menyisakan sistem dua-partai yang dimonopoli oleh $\mathrm{AD}$ dan COPEI, sampai sistem puntofijismo berakhir. Presiden Betancourt menuding MIR dan kelompok komunis sebagai pihak yang bertanggungjawab terhadap kerusuhan yang terjadi, dan mencabut jaminan konstitusional bagi PCV yang akhirnya memaksa PCV untuk melakukan aktivitas bawah tanah. Pada akhir 1961, MIR dan PCV mempersiapkan perlawanan gerilya bersenjata. Pada bulan April 1962 aksi pemberontakan pertama dilakukan, yang disusul berbagai pemberontakan lainnya. Salah satu pemberontakan dilakukan oleh unit Angkatan Laut di daerah Carúpano and Puerto Cabello pada Mei-Juni 1962, yang diinspirasikan oleh simpati mereka terhadap ide-ide kelompok sayap-kiri. Pemberontakan ini berhasil dihancurkan, dengan korban jiwa yang cukup besar.20 Meskipun pemberontakan militer tersebut gagal-total, karena tidak dipersiapkan secara memadai, namun pemberontakan militer ini merupakan sesuatu yang sangat penting, sebagai indikasi mengenai derajat patriotisme dan sentimen sosial progresif di kalangan angkatan bersenjata, sekaligus merupakan suatu hal penting dalam memahami akar dari gerakan Bolivarian ala Chávez. Kelompok-kelompok gerilya bersenjata tersebut kemudian meleburkan diri dan membentuk front bersama dengan nama Fuerzas Armadas de Liberación Nacional (FALN) atau Armed Forces of National Liberation dengan lembaga politik klandestin Frente de Liberación Nacional (FLN) atau National Liberation Front. Panglima FALN adalah Kapten Manuel Ponte Rodríguez, salah seorang pimpinan pemberontakan Puerto Cabello, yang memprok- lamirkan tujuan perjuangan mereka sebagai perluasan nasionalis, demokratis dan anti-imperialis untuk:

[...] to enforce respect for national sovereignty and independence, the freedom and democratic life of the Venezuelan people... to set up a revolutionary, nationalist and democratic government.

Ketiga, dilihat dari sudut perspektif komparatif, termasuk interaksi antara lembagalembaga perwakilan, konstituen sosial dan konteks struktural, terutama kebijakan ekonomi pasar yang merujuk pada Amerika Serikat, persoalan clientelism saling bertaut dengan krisis ekonomi. Juga krisis terhadap industri subtitusi impor pada 1980AN, dan pergeseran ke arah neoliberalisme pada 1990AN merupakan titik-balik dalam pembangunan politik di Amerika Latin, terutama akibat jatuhnya harga minyak mentah, sebagai sumber utama ekonomi Venezuela. Selama pemerintahan rejim puntofujismo, jurang kaya-miskin di Venezuela terbentang sangat lebar. Pada pertengahan 1990AN, GDP perkapita Venezuela menurun tajam sampai 20 persen dari puncaknya di era 1970AN, dan kue ekonomi itu pun distribusinya sangat tidak merata, di mana pendapat kalangan paling miskin yang jumlahnya 40 persen dari populasi merosot dari 
Konfrontasi: Jurnal Kultur, Ekonomi dan Perubahan Sosial, 1 (2) Juli 2014, 56-73

P-ISSN: 1410-881X (Print)

Daniel Hutagalung, Hugo Chávez dan Kebangkitan Populisme-Kiri Amerika Latin: Venezuela Era Hugo Chávez (1998-2006)

DOI: -

http://www.konfrontasi.net/index.php/konfrontasi2

19.1 persen pada tahun 1981 menjadi 14.7 persen pada tahun 1997, sedangkan 1 dari 10 orangorang kaya pendapatannya meningkat dari 21.8 persen menjadi 32.8 persen. Dari tahun 1984 sampai 1993, persentase populasi yang hidup di bawah garis kemiskinan meningkat dari

36 persen menjadi 62 persen, sementara persentase yang hidup dalam kemiskinan ekstrim (extreme poverty) naik tiga kali lipat, dari 11 persen menjadi 33 persen.

Ketiga hal tersebut tidak berhasil diantisipasi pemerintahan puntofujismo dengan kebijakan-kebijakan yang dibuat, bahkan semakin menumbuhkan ketidakpuasan rakyat terhadap berbagai kebijakan yang diambil oleh partai- partai politik dominan yang menguasai pemerintahan. Ketidakpuasan rakyat yang semakin meluas berakibat terjadinya kerusuhan pada 1989 yang menyebabkan ratusan korban jiwa, dan kemudian disusul terjadinya dua kali kudeta militer di tahun 1992 untuk menggulingkan kepemimpinan Presiden Carlos Andrés Pérez. Pemberontakan melalui jalur kudeta militer tersebut dipimpin oleh Letnan Kolonel Hugo Chávez Frías dengan gerakan Movimiento Bolivariano 200 (MBR-200) yang berujung pada kegagalan. Chávez ditangkap dan dipenjara.

Meskipun mengalami kegagalan, kudeta 1992 dan terjadinya krisis telah mendorong perubahan dalam kepolitikan Venezuela. Enam bulan setelah terjadinya kudeta yang gagal, Presiden Carlos Andrés Pérez mengalami impeachment, lalu diadakan pemilu pada 1993 di mana Rafael Caldera berhasil memenangi kursi kepresidenan dengan dukungan aliansi 19 partai politik yang tergabung dalam Convergencia Nacional (CN). Pemilu 1993 menjadi momentum politik baru, karena untuk pertama kalinya presiden Venezuela bukan berasal dari AD atau COPEI. Hasil pemilu 1993 sekaligus mengakhiri dominasi AD dan COPEI semenjak tahun 1958. Pada bulan Maret 1994, setelah ditahan selama kurang lebih dua tahun, Chávez dan rekan- rekannya - yang ditahan karena melakukan kudeta - memperoleh amnesti dari presiden terpilih Rafael Caldera.

Semenjak pemberontakan yang gagal tersebut nama Chávez mulai dikenal publik Venezuela. Ini terlihat lewat sebuah survei yang dilakukan pada tahun 1995 dengan tujuan untuk menyusun daftar orang-orang yang paling berpengaruh di Venezuela. Survei ini dirancang untuk mendapatkan masukan nama-nama figur terkemuka yang tidak berafiliasi dengan partai politik besar. Dalam daftar hanya terdapat tujuh nama yang disajikan, namun responden dapat menuliskan nama orang yang tidak terdapat di dalam daftar tersebut. Nama-nama yang dicantumkan di dalam daftar adalah: Arturo Uslar Pietri, intelektual yang sangat masyhur yang memainkan peran kunci sebagai kritikus politik; José Vicente Rangel, wartawan terkemuka; Monsignor Ali

Lebrún, pemimpin gereja; Andrés Velásquez, kandidat presiden pada pemilu 1993 dari partai kiri La-Causa-R; Edgar Romero Navas, seorang pengusaha; Federico Ramírez León, pemimpin serikat buruh; dan Hugo Chávez. Dari 897 responden, 790 menyebut nama orang yang mereka anggap paling berpengaruh di Venezuela dari daftar 
Konfrontasi: Jurnal Kultur, Ekonomi dan Perubahan Sosial, 1 (2) Juli 2014, 56-73

P-ISSN: 1410-881X (Print)

Daniel Hutagalung, Hugo Chávez dan Kebangkitan Populisme-Kiri Amerika Latin: Venezuela Era Hugo Chávez (1998-2006)

DOI: -

http://www.konfrontasi.net/index.php/konfrontasi2

yang ada dalam list, hanya 36 kasus yang menyebut nama lain di luar tujuh nama tersebut. Hasil survei tersebut menempatkan nama Hugo Chávez di urutan ketiga.

Dalam survei tersebut menujukkan bahwa Chávez merupakan salah satu tokoh yang diharapkan bisa membawa perubahan dan pembaharuan di Venezuela. Nama Chávez menonjol selain karena dikenal dengan percobaan kudetanya pada 1992, namun juga karena presiden terpilih pada pemilu 1993 yakni Rafael Caldera, membela posisi Chávez dalam melakukan kudeta tahun 1992 dalam kampanye-kampanyenya. Semenjak itu nama Chávez semakin meroket dan dikenal semakin luas, serta dianggap sosok pembaharu bagi Venezuela yang sedang mengalami krisis ekonomi yang hebat.

Chávez kemudian melanjutkan perjuangan politiknya, yang gagal pada tahun 1992, tidak lagi melalui jalur pemberontakan, melainkan melalui jalur elektoral dengan membangun organisasi politik yang ia namakan Movimiento Quinta República (Fifth Republic Movement) atau Gerakan Republik Kelima yang populer disingkat MVR, dengan tujuan mewujudkan suatu sistem demokrasi partisipatoris, yang dalam bahasa Chávez, akan mampu:

[...] gradually eliminates the savage system of income distribution that exist in Venezuela, that progressively eliminates the great difference Chávez menjanjikan disusunnya undangundang dasar (konstitusi) baru, mentransformasikan Venezuela ke arah demokrasi sejati, dan mengedepan- kan ide-ide penolakan dominasi Amerika Serikat di wilayah Amerika Selatan.27 Chávez dan MVR mendapatkan dukungan luas rakyat Venezuela. Kudeta gagal yang dilakukan Chávez pada 1992 tidak membuat dirinya menjadi figur yang tidak populer, melainkan justru menjadi figur yang popularitasnya meningkat tajam, bahkan muncul demonstrasi dan rally yang menuntut pembebasan Chávez dari penjara. Survei opini publik yang dilakukan pada waktu itu, mengafirmasi dukungan substansial rakyat kepada Chávez. Dalam laporan Angela Zago, jajak opini yang dilakuan empat bulan setelah kudeta yang gagal menujukkan bahwa Chávez memiliki citra positif di mata 67.4 persen warga Caracas, ibukota Venezuela. Juga survei-survei yang dilakukan setelahnya yakni pertengahan 1993 dan 1995. Mulai tahun 1996 nama Chávez secara konsisten selalu muncul sebagai alternatif ketiga dalam preferensi pemilih yang layak maju sebagai presiden untuk pemilu 1998. Pada jajak opini yang dilakukan tahun 1996, Chávez menduduki tempat ketiga dengan 9.7 persen. Dalam studi Canache dan Raby, disebutkan bahwa semenjak dibebaskan dari penjara, Chávez giat melakukan sosialisasi kepada kelompok-kelompok rakyat miskin seantero Venezuela, dan membangun aliansi dengan kelompok-kelompok kiri seperti: Polo Patriótico, PCV, Movimiento al Socialismo (MAS) dan La Causa Radical (LCR).

Pada Pemilu 1998, Chávez memenangkan kursi kepresidenan, dengan memperoleh 56 persen suara, mengalahkan calon lainnya yakni Salas Römer yang memperoleh 39 persen. Kepemimpinan Chávez dalam kudeta militer gagal pada tahun 1992 telah membuat dirinya memiliki semacam sebagai seorang "political outsider". 
Konfrontasi: Jurnal Kultur, Ekonomi dan Perubahan Sosial, 1 (2) Juli 2014, 56-73

P-ISSN: 1410-881X (Print)

Daniel Hutagalung, Hugo Chávez dan Kebangkitan Populisme-Kiri Amerika Latin: Venezuela Era Hugo Chávez (1998-2006)

DOI: -

http://www.konfrontasi.net/index.php/konfrontasi2

Posisi tersebut merupakan keunggulan dan keuntungan Chávez dalam memenangi pemilihan presiden, karena Chávez tidak diidentifikasikan sebagai bagian dari rezim lama yang bobrok dan korup, melainkan sebagai "orang di luar panggung politik", yang bersih dan membawa pembaharuan. Semenjak itu, dimulailah "Revolusi Bolivarian” yang dicanangkan Hugo Chávez, yang banyak dinilai sebagai faktor penting yang mendorong kebangkitan gerakan populis-kiri yang merebak di Amerika Latin.

"Revolusi Bolivarian": Pembangunan Politik Ala Hugo Chávez

Ketertarikan banyak orang pad ide-ide Chávez adalah premisnya mengenai tiga hal pokok. Pertama, Chávez menjanjikan sebuah "Revolusi Bolivarian” yang akan menyapu bersih negara Punto Fijo dan menjanjikan lahirnya negara baru Republik Kelima. Istilah "Bolivarianisme" diambil Chávez dari nama Simón Bolívar, pahlawan pembebasan wilayah Andes, Amerika Selatan, dari kolonialisme Spanyol abad sembilanbelas. Simón Bolívar merupakan pahlawan nasional di Venezuela, dan dengan menggunakan warisan sejarah Bolívar, Chávez memobilisasi rasa kebanggaan nasional dan perasaan senasib yang menurut Chávez telah diselewengkan oleh rejim puntofijistas. Menurut Chávez dan para pendukungnya (Chavistas), potensi yang dimiliki bangsa Venezuela telah dihambur- hamburkan dengan sia-sia oleh oligarkhi Punto Fijo. Tujuan para chavistas adalah untuk merebut kembali warisan Bolívar dan menghubungkan kembali negara kepada rakyat yang berdaulat atau el pueblo. Ide model demokrasi langsung sebagaimana ditawarkan Chávez mendapat banyak dukungan rakyat, terutama setelah dominasi politik oleh Partai AD dan COPEI selama puluhan tahun. Pokok tawaran ide Bolivarian dari Chávez adalah komitmen untuk perubahan konstitusi. Penggantian konstitusi 1961 dilihat sebagai sesuatu yang esensial untuk melakukan pembersihan terhadap institusiinstitusi lama, dan memperdalam demokrasi serta membersihkan korupsi. Ide-ide Bolivarian secara luas menjadi platform rakyat banyak yang merasa frustrasi terhadap kegagalan AD dan COPEI untuk melakukan modernisasi sistem politik.

Kedua, bersamaan dengan komitmen pada demokrasi partisipatif, Revolusi Bolivarian memasukkan agenda sosial yang akan memberikan keadilan untuk semua yang disediakan oleh negara dalam bentuk kesejahteraan, kebudayaan, kesempatan dalam perumahan, dan prioritas akan diberikan kepada warga yang hidup sangat miskin (extreme poverty). Dalam bidang ekonomi, Chavistas menekankan pada penguatan harga minyak internasional dan peningkatan keuntungan pendapatan bagi rakyat Venezuela dari industri minyak nasional. Juga diversifikasi dari ketergantungan pada pendapatan ekspor minyak kepada pendapatan non-minyak melalui pajak pendapatan dan pajak perusahaan. Penekanan dilakukan pada peningkatan intensifitas usaha kecil dan menengah, dan gerakan koperasi, dalam rangka peningkatan tenaga kerja dan mendorong kedaulatan pangan. Ambisi program ini adalah untuk mematahkan struktur oligopoli dalam ekonomi Venezuela, di mana kekayaan industri, perkebunan dan pertanian hanya berada di tangan segelintir elit kecil. Tujuan pokok lainnya adalah integrasi topografi teritori nasional yang demikian beragam, di mana 
Konfrontasi: Jurnal Kultur, Ekonomi dan Perubahan Sosial, 1 (2) Juli 2014, 56-73

P-ISSN: 1410-881X (Print)

Daniel Hutagalung, Hugo Chávez dan Kebangkitan Populisme-Kiri Amerika Latin: Venezuela Era Hugo Chávez (1998-2006)

DOI: -

http://www.konfrontasi.net/index.php/konfrontasi2

Chavistas menjanjikan investasi yang substansial dalam bidang infrastruktur, transportasi, energi nasional, dan jaringan sungai.32

Ketiga, aspek penting lainnya dari Revolusi Bolivarian berkaitan dengan kebijakan luar negeri. Pemerintahan Chávez menawarkan terciptanya tata- dunia yang multipolar yang didasarkan pada blok-blok kekuasaan yang dapat memperlemah dominasi unipolar dari Amerika Serikat. Integrasi regional dengan negara-negara Amerika Selatan lainnya merupakan target kunci, yang segaris dengan visi Simon Bolivar mengenai persatuan benua Amerika Selatan untuk melawan kekuatan dari wilayah Utara.

Chávez menjalankan berbagai program dalam rangka pembangunan politik. Istilah "pembangunan politik" sendiri secara eksplisit mulai digunakan pada tahun 1960An dalam artian menggambarkan proses yang biasa disebut "modernisasi politik" oleh negara- negara yang baru mengalami dekolonisasi atau negara berkembang lainnya.33 Titik perhatian utama dalam analisa politik adalah bagaimana melihat pembangunan komunitas politik yang stabil yang lebih-kurang dapat mengikuti alur yang dibuat oleh negara-negara maju. Menurut Kingsbury, pembangunan politik dapat dilihat sebagai sesuatu, hanya jika dapat mencapai proyek "nation-building" kaum modernis, yang utamanya adalah diidentifikasikan dengan pembangunan ekonomi, dan ini membutuhkan stabilitas dan keteraturan politik.34 Dengan merujuk pada pandangan Kingsbury maka program "Revolusi Bolivarian" Chávez yang berkaitan dengan pembangunan politik bisa diidentifikasi pada proyek:

Pembangunan Organisasi. Tujuan dari transformasi organisasi Chávez yakni MVR menjadi partai berbasis massa dengan pemilihan internal untuk memilih para pemimpinnya pada seluruh lapisan dan tingkat, dimaksudkan untuk menghilangkan personalisme yang terlanjur menjadi "cap" gerakan Chavista. Untuk membangun kekuatan popularnya, Chávez mendirikan berbagai macam organisasi sosial, sebagai bentuk koreksi terhadap karakter dan sistem dominasi partai atas masyarakat sipil, sebagaimana terjadinya di era Punto Fijo. Salah satu kelompok sosial yang paling menonjol adalah "Círculos Bolivarianos" (Bolivarian Circle) atau "Lingkaran Bolivarian" yang dibentuk Chávez pada tahun 2000, sebagai bagian dari strategi jangka panjang untuk mengorganisir gerakan Bolivarian yang dipimpinnya menuju revolusi demokratis. Setiap Círculo terdiri dari 11 orang anggota yang bersumpah untuk mempertahankan konstitusi, setia pada ide-ide Simón Bolívar dan melayani kepentingan komunitas. Dalam beberapa tahun Círculos Bolivarianos berhasil merengkuh 2.2 juta anggota. Círculos ini jugalah yang memainkan peran sangat penting dalam demonstrasi besar yang mendukung Chávez saat dikudeta pada April 2002, dan memfasilitasi program pengentasan kemiskinan yang dijalankan pemerintah, dan ikut berkampanye dalam pemilihan presiden.

Pembangunan Institusi. Konstitusi 1999 menyediakan mekanisme pembuatan- keputusan popular sebagai jawaban terhadap model personalisme dan clientelism yng 
Konfrontasi: Jurnal Kultur, Ekonomi dan Perubahan Sosial, 1 (2) Juli 2014, 56-73

P-ISSN: 1410-881X (Print)

Daniel Hutagalung, Hugo Chávez dan Kebangkitan Populisme-Kiri Amerika Latin: Venezuela Era Hugo Chávez (1998-2006)

DOI: -

http://www.konfrontasi.net/index.php/konfrontasi2

berlangsung selama rezim puntofijismo. Perubahan konstitusi melalui referendum nasional pada Desember 1999, menjadikan peran partai-partai politik semakin berkurang, karena adanya mekanisme partisipasi langsung melalui referendum, plebisit dan pemilu ulang. Konstitusi 1999 menjanjikan dihentikannya kebijakan neoliberal yang sudah berlangsung selama sepuluh tahun, dengan menerapkan model campur-tangan negara dalam bidang ekonomi sekaligus penegasan mengenai tanggungjawab negara untuk mensejahterakan populasi masyarakat yang berada di sektor-sektor yang diabaikan (kaum miskin kota, petani, buruh, dan lain-lain).36 Meskpun demikian, institusionalisasi demokratis merupakan suatu hal yang jauh lebih sulit untuk bisa dicapai ketimbang demokratisasi partai.

Inkorporasi Sektor-sektor yang Diasingkan. Sebagaimana populisme klasik memasukkan buruh dari sektor ekonomi formal pada saat jumlah mereka bertambah besar sesuai dengan mulai berkembangnya industrialisasi, Chavista juga menarik perhatian sektor- sektor yang jumlahnya terus bertambah akibat hasil dari globalisasi dan politik neoliberal. Basis sosial pendukung Chávez terdiri dari anggota masyarakat dari kelas sosial yang terpinggirkan dari sektor ekonomi informal, serta kaum buruh miskin yang bukan anggota serikat buruh sektor ekonomi formal. Dalam kasus populisme klasik, mobilisasi sektor-sektor yang tidak diuntungkan menjadi esensial bagi keberlangsungan pemerintahan di hadapan oposisi yang siap mengadakan pemberontakan atau perlawanan. Ini implisit di dalam diskursus Chávez mengenai zero-sum game yang memberikan keistimewaan kepada strata yang lebih rendah di dalam populasi.37 Preferensi sosial semacam ini biasa disebut kebijakan redistribusi dari populis klasik.

Transformasi Budaya. Efek jangka panjang yang bisa diperkirakan dari fenomena dari kepemimpinan Chávez adalah dampaknya terhadap peikiran dan perilaku dari rakyat Venezuela. Pengaruh ini muncul dalam berbagai macam bentuk: mobilisasi tingkat tinggi di antara baik pendukung maupun anti Chávez, yang mana secara bertahap namun pasti membentuk mereka dalam artian penguatan (empowerment) dan juga di mana jurubicara pemerintah menyebutnya sebagai sebuah contoh dari "demokrasi partisipatif". Keterlibatan banyak Chavistas dalam berbagai diskusi mengenai topik-topik nasional, terutama topik-topik yang diangkat presiden dalam pidato-pidatonya di televisi, tuntutan kepada kebanggan etnis dan ras, stimulasi nasionalisme melalui peninjauan-kembali sejarah Venezuela dengan memberikan penekanan kepada kepahlawanan dan kepada perjuangan- perjuangan tertentu.

Chávez juga memperkuat pembangunan politiknya dengan mandanai program-program sosial yang ia namakan "missions to save the people", yang merupakan program sosial yang dananya diambil dari keuntungan perusahaan minyak milik pemerintah yakni Petróleos de Venezuela Sociedad Anónima (Venezuelan Oil Company, Incorporated) atau PDVSA. Misimisi tersebut dimulai dengan program kesehatan di wilayah-wilayah paling miskin di Venezuela, khususnya di kota-kota gubug di pusat urbanisasi (Misión Barrio Adentro). Setelah itu sejumlah misi (yang dalam bahasa Spanyol misiones) disediakan untuk beragam jenis 
Konfrontasi: Jurnal Kultur, Ekonomi dan Perubahan Sosial, 1 (2) Juli 2014, 56-73

P-ISSN: 1410-881X (Print)

Daniel Hutagalung, Hugo Chávez dan Kebangkitan Populisme-Kiri Amerika Latin: Venezuela Era Hugo Chávez (1998-2006)

DOI: -

http://www.konfrontasi.net/index.php/konfrontasi2

pelayanan sosial, dari pengajaran baca-tulis di wilayah pedesaan dan urban (Misión Robinson), untuk membantu orang-orang dewasa belajar untuk tingkat sekolah menengah atas (Misión Ribas). Pemerintahan Chávez juga memfokuskan pada kebutuhan warga atas kartu identitas (Misión Identidad), di mana kartu tersebut merupakan syarat untuk mendapatkan akses transfer uang tunai yang dihibahkan kepada rakyat untuk mendorong mereka berpartisipasi dalam program-program sosial, dan juga diperlukan untuk ikut pemilu. Pemerintahan Chávez juga menyusun program untuk mendistribusikan subsidi pangan secara langsung kepada kaum miskin, dengan membuat took- toko diskon di seluruh negara (Misión Mercal). Juga program pemerintahan

Chávez lainnya yang bertujuan untuk menciptakan pekerjaan melalui promosi koperasi (Misión Vuelvan Caras).

Selain itu, di tingkat regional Amerika Latin, Chávez merupakan inisiator bagi pembentukan semacam integrasi regional untuk membentengi Amerika Latin dari agresi Amerika Serikat, khususnya semasa kepemimpinan Presiden George W. Bush. Venezuela di bawah Chávez muncul sebagai penentang kebijakan Free Trade Are of the America (FTAA) yang diinisiasi oleh AS, yang akan menciptakan zona perdagangan- bebas di seluruh benua Amerika. Bersama Brasil, Venezuela memblokade ratifikasi FTAA pada tahun 2004, dan membentuk model tandingan yang dinamakan Bolivarian Alternative for the Americas (ALBA). Program FTAA ditekankan pada pembukaan pasar bebas, dan perdagangan barang secara bebas di antara negara-negara Amerika, ALBA justru menekankan pada pengakuan keunggulan komparatif tidap-tiap negara, kerja sama, solidaritas regional dan keadilan sosial.39 Kuba, Bolivia, Nikaragua, Republik Dominika dan Ekuador merupakan anggota ALBA semenjak 2007, dan kesepakatan yang didasarkan pada prinsip ALBA ditandatangani bersama Argentina dan Brasil.

Proyek politik Chávez, terutama dalam pembangunan politik, merupakan model populisme, jika merujuk pada argumen Francisco Panizza, di mana syarat-syarat kemunculan populisme semua ada dalam gerakan yang dibangun Chávez. Meskipun, Chávez kemudian mengarahkan proyek politiknya pada jalan sosialisme, dengan mendorong pembangunan politik ala Marxian dan Bolivarian, secara sekaligus, sebagaimana dinyatakan Chávez: "The fight for justice, the fight for equality and the fight for liberty, some call ,,socialism ${ }^{\mathrm{ee}}$, others, „Christianity"e ; we call it „Bolivarianism ${ }^{\text {ee }}$.

\section{Negara dan Birokrasi}

Faktor penting dalam popularitas Chávez adalah statusnya sebagai “orang luar” (political outsider) dalam rezim politik Punto Fijo dan tidak memiliki keterkaitan dengan rezim tersebut, dan Chávez juga dipandang sebagai "orang kuat" yang sangat dihormati yang tidak akan berkompromi dalam mewujud- kan reformasi. Setelah memenangkan pemilu, Chávez segera melakukan perubahan sebagaimana dia janjikan, yakni: melakukan referendum untuk mengubah konstitusi dan mengubah nama negara menjadi Republik Bolivarian 
Konfrontasi: Jurnal Kultur, Ekonomi dan Perubahan Sosial, 1 (2) Juli 2014, 56-73

P-ISSN: 1410-881X (Print)

Daniel Hutagalung, Hugo Chávez dan Kebangkitan Populisme-Kiri Amerika Latin: Venezuela Era Hugo Chávez (1998-2006)

DOI: -

http://www.konfrontasi.net/index.php/konfrontasi2

Venezuela. Untuk itu, dengan mendapatkan dukungan dari Mahkamah Agung, Chávez mengeluarkan dekrit presiden untuk menyeleng- garakan referendum untuk memilih semacam Majelis Rakyat (Constituent Assembly) yang memiliki kekuasaan orisinil dan absolut. Pada Arpil 1999, Chávez berhasil mendapatkan dukungan rakyat untuk referendum, di mana 81 persen rakyat mendukung inisiatif tersebut, dan pada akhir 1999 majelis konstituante terpilih.

Dalam konstitusi baru yang diberi nama Konstitusi Bolivarian, rezim Chávez merombak konstitusi Punto Fijo yang salah satunya mengubah masa jabatan presiden menjadi enam tahun dari sebelumnya lima tahun dalam satu masa jabatan. Konstitusi ini merupakan konstitusi antineoliberal, yang disepakati oleh mayoritas rakyat, dan dalam Konstitusi Bolivarian, didefinisikan sebuah model demokrasi partisipatif, dan model ekonomi baru yang merangkul koperasi dan model pengaturan sendiri bagi para buruh (worker self- management). Kedua model tersebut secara fundamental didasarkan pada humanisme dan solidaritas.

Berdasarkan referendum dan konstitusi baru, Chávez menyelenggarakan pemilu pada tahun 2000 untuk memilih presiden, gubernur, walikota dan deputi-deputi untuk Majelis Nasional, sesuai dengan perubahan yang ada dalam konstitusi baru. Rezim Chávez berhasil memenangkan pemilu dengan signifikan.42 Selama pemerintahan Chávez sampai tahun 2006, sejumlah pemilu diselenggarakan untuk memperkuat birokrasi pemerintahan, misalnya dua kali pemilu untuk memilih anggota legislatif dalam enam tahun, di mana dalam dua pemilu tersebut para pendukung Chávez memenangkan suara mayoritas, dan setelah referendum, rezim Chávez menguasai 22 dari 24 states (provinsi), dan menguasasi mayoritas dalam pemilihan tingkat kota (municipal) yakni 260 dari 335 municipals.

Sebaliknya, pihak oposisi berkali-kali mencoba manjatuhkan Chávez dari kursi kepresidenan lewat jalur ekstrakonstitusional. Misalnya, pada bulan April 2002, angkatan bersenjata menarik dukungan mereka terhadap presiden Chávez, setelah demontrasi massa di depan Istana Kepresidenan berakhir dengan pertumpahan darah. Sejumlah jenderal dalam angkatan bersenjata, termasuk Jenderal Efraín Vásquez Velasco, panglima angkatan bersenjata, menahan dan memaksa Chávez untuk mengundurkan diri. Dalam beberapa jam kemudian, pejabat senior angkatan bersenjata Venezuela, yakni Jenderal Lucas Rincón Romero, mengumumkan bahwa Presiden Chávez sudah mengeluarkan pernyataan mengundurkan diri.44 Kudeta ini didukung kuat oleh kalangan bisnis dan usaha di lingkungan elit Venezuela. Namun, Chávez menolak menandatangani surat pengunduran diri dan menolak untuk diterbangkan ke Kuba. Pada saat Chávez ditahan, oposisi mengangkat presiden de facto yakni Pedro Carmona, seorang konglomerat. Namun, dalam dua hari militer menolak mendukung Carmona, dan sebuah faksi pasukan elit dalam militer Venezuela yang dipimpin Jenderal Raúl Baduel, memimpin pembebasan Chávez dan mengembalikan Chávez ke kursi kepresidenan. 
Konfrontasi: Jurnal Kultur, Ekonomi dan Perubahan Sosial, 1 (2) Juli 2014, 56-73

P-ISSN: 1410-881X (Print)

Daniel Hutagalung, Hugo Chávez dan Kebangkitan Populisme-Kiri Amerika Latin: Venezuela Era Hugo Chávez (1998-2006)

DOI: -

http://www.konfrontasi.net/index.php/konfrontasi2

Kudeta tahun 2002 yang gagal memberikan dalih bagi pemerintahan Chávez untuk mengganti elemen-elemen yang tidak memiliki loyalitas di dalam tubuh angkatan bersenjata. Kelompok-kelompok di dalam tubuh militer yang tidak mau bekerja sama dan tunduk kepada otoritas kekuasaan pemerintah dibersihkan, termasuk juga dalam tubuh lembaga peradilan, dan lembaga- lembaga negara lainnya. Kalangan generasi muda dan baru dari para aktivis dan chavistas dimasukkan untuk menggantikan para pejabat dan pegawai pemerintahan yang melakukan pembangkangan.

Demikian juga terhadap sektor privat dan bisnis yang ikut mendukung kudeta gagal tahun 2002, di mana keterlibatan dan partisipasi perusahaan Fedecamaras dalam protes-protes antipemerintahan dan upaya kudeta, mendorong Chávez untuk meyakini bahwa kelompok bisnis Fedecamaras tidak dapat dipertimbangkan lagi sebagai mitra dalam melaksanakan pembangunan. Pemerintah kemudian mencari mitra baru, yakni perusahaan asing, untuk melakukan investasi dan usaha patungan. Hukuman yang dijatuhkan terhadap dunia bisnis adalah penatapan harga dan kontrol nilai- tukar pada 2002. Dengan maksud untuk melindungi permodalan dari "pendarahan" dan memastikan akses terhadap kebutuhan dasar bagi orang- orang miskin yang dirundung instabilitas, rencana tersebut membatasi kebebasan beroperasi dan akses terhadap pasar bagi kelompok-kelompok bisnis raksasa yang sebelumnya berkuasa.

Nasionalisasi perusahaan minyak Petróleos de Venezuela Sociedad Anónima (PDVSA), sebagai perusahaan minyak terbesar di Venezuela, merupakan salah satu upaya Chávez untuk menguasai pendapatan sektor minyak. PDVSA pada awalnya merupakan perusahaan negara, yang kemudian diprivatisasi, dan kembali dinasionalisasi. Para elit PDVSA merupakan tokohtokoh oposisi yang mendukung kudeta 2002, di mana mereka juga memimpin mogok kerja buruh PDVSA selama berbulan-bulan, untuk menjatuhkan Chávez dari kursi kepresidenan. Setelah berhasil mengalahkan kudeta, Chávez memecat 18,000 manajer dan teknisi PDVSA, dan meluncurkan PDVSA sebagai perusahaan negara Bolivarian, dengan motto "belonging to everyone".46 PDVSA kemudian menjadi lumbung bagi pendanaan program-program sosial yang dijalankan pemerintahan Chávez, di mana keuntungan yang diperolah PDVSA, terutama pada saat naiknya harga minyak secara drastis, merupakan pendukung utama pendanaan program sosial yang dinamakan "mission to save the people".

\section{Penutup}

Dengan merujuk pada argumen Panizza di awal tulisan, empat kondisi kemunculan populisme bisa ditemukan dalam kasus Venezuela dan Hugo Chávez, di mana Chávez tampil dalam situasi kondisi krisis perekonomian dan krisis politik, di mana kepercayaan rakyat terhadap politik menurun drastis, yang ditandai dengan kalahnya sistem dwi-partai AD dan COPEI dalam pemilu 1993, di mana presiden dari koalisi non AD dan COPEI yang memenangkan pemilu, meskipun demikian ketidakpuasan rakyat terus berlanjut, dan kemunculan Chávez sebagai political outsider, atau orang yang 
Konfrontasi: Jurnal Kultur, Ekonomi dan Perubahan Sosial, 1 (2) Juli 2014, 56-73

P-ISSN: 1410-881X (Print)

Daniel Hutagalung, Hugo Chávez dan Kebangkitan Populisme-Kiri Amerika Latin: Venezuela Era Hugo Chávez (1998-2006)

DOI: -

http://www.konfrontasi.net/index.php/konfrontasi2

tidak tersangkut rezim masa lalu yang korup menjadi nilai tersendiri bagi harapan terhadap suatu yang baru, dan MVR organisasi bentukan Chávez terdiri dari orang- orang yang tidak memiliki keterkaitan denga rezim masa lalu. Kelompok-kelompok sosial baru, terutama kaum miskin perkotaan di Venezuela muncul menjadi kekuatan politik baru bersama MVR dan Chávez, identitas politik yang sebelumnya tidak direpresentasikan, kemudian dipresentasikan lewat MVR, kelompok yang menjadi korban globalisasi dan krisis ekonomi, maupun pertumbuhan industri perkotaan.

Meskipun demikian populisme merupakan suatu hal yang lebih dari sekedar respon terhadap kekacauan politik, melainkan suatu gambaran yang telah sedemikian berurat-akar mengenai bagaimana politik dijalankan, diturunkan dari rentang yang terbangun eksis antara pemimpin dan yang dipimpin, dan kesulitan yang dihadapi organisasi politik dalam memediasinya secara efektif. Program politik Chávez adalah cara bagaimana politik dijalankan, dengan menjalankan pembangunan politik, Chávez menata kekuatan politiknya sekaligus membangun kekuatan birokrasi untuk menjaga keutuhan kekusaaan dan kedaulatan rakyat yang ia pimpin.

Proyek politik Chávez, sebagaimana dinyatakan Ellner sebagai non- revolutionary path of radical populism, dinyatakan melalui berbagai program politik misi- misi, yakni mendorong program sosial secara revolusioner, namun bukan dalam proyek politik revolusi, setidaknya selama kekuasaan Chávez sepanjang 1998-2006. Namun, Ellner menyinggung bahwa non- revolutionary path of radical populism juga bisa mengarah pada revolutionary-path, artinya poryek politik Chávez masih belum selesai dan masih dimungkinkan terjadinya berbagai perubahan, apakah "Revolusi Bolivarian" akan berbentuk non-revolutionary transformation, atau justru revolutionary-path.

Amandemen konstitusi, membentuk Circulos Bolivarianos, mengembangkan programprogram sosial, menguasasi politik lokal, dan menempatkan orang- orang yang loyal untuk menggantikan oposisi yang tidak loyal dalam institusi pemerintahan, serta mengambil-alih perusahaan minyak terbesar merupakan upaya Chávez menjalankan politik "Revolusi Bolivarian" yang masih bertahan sampai hari ini.

Selamat jalan El Comandante Hugo Chávez... Hasta la victoria siempre...

\section{Bibliografi}

Bruce, Iain, The Real Venezuela: Making Socialism in the 21st Century (London: Pluto Press, 2008).

Buxton, Julia, "Venezuelaes Bolivarian Revolution”, Global Dialogue, NO.10 (2008).

Canache, Damarys, "From Bullets to Ballots: The Emergence of Popular Support for Hugo Chávez", Latin America Politics and Society, Vol.44 (NO.1) (Spring 2002).

Derham, Michael, "Undemocratic Democracy: Venezuela and the Distorting of History", Bulletin of Latin American Research, VOL.21 (NO.2) (April 2002). 
Konfrontasi: Jurnal Kultur, Ekonomi dan Perubahan Sosial, 1 (2) Juli 2014, 56-73

P-ISSN: 1410-881X (Print)

Daniel Hutagalung, Hugo Chávez dan Kebangkitan Populisme-Kiri Amerika Latin: Venezuela Era Hugo Chávez (1998-2006)

DOI: -

http://www.konfrontasi.net/index.php/konfrontasi2

Ellner, Steve, "Revolutionary and Non-Revolutionary Paths of Radical Populism: Directions of the Chavista Movement in Venezuela", Science and Society, Vol.69, (NO.2) (April 2005).

Frías, Hugo Chávez, "Statement by H. E. Hugo Chávez Frías, President of the Bolivarian Republic of Venezuela at the 61st United Nations General Assembly", New York, September 20th, 2006, dalam Law and Business Review of the Americas, 12 (4) (Fall 2006).

Gott, Richard, Rural Guerrillas in Latin America (Harmondsworth: Penguin, 1973). Harnecker, Marta, "After the Referendum: Venezuela Faces New Challenges", Monthly Review, Vol.56 (No.6) (November 2004).

Hawkins Kirk A., and David R. Hansen, "Dependent Civil Society: The Círculos Bolivarianos in Venezuela", Latin America Research Review, VOL.41 (No.1) (2006).

Kingsbury, Damien, Political Development (London: Routledge, 2007). Myers, David J., "The Normalization of Punto Fijo Democracy" dalam Jennifer

L. McCoy and David J. Myers (Eds), The Unravelling of Representative

Democracy in Venezuela (Baltimore: The Johns Hopkins University Press, 2006).

McCoy Jennifer, and Laura Neuman, "Defining the „Bolivarian Revolution": Hugo Chávezees Venezuela”, Current History, Vol. 100 (643) (February 2001).

Nelson, Brian A., The Silence and the Scorpion: The Coup Against Chávez and the Making of Modern Venezuela (New York: Nation Books, 2009).

Panizza, Francisco, "Populism and the Mirror of Democracy" dalam Francisco Panizza (Ed), Populism and the Mirror of Democracy (London: Verso, 2005).

Panizza, Fransisco, and Romina Miorelli, "Populism and Democracy in Latin America" dalam Ethics and International Affair, 23 (1) (Spring 2009).

Penfold-Becerra, Michael, "Clientelism and Social Funds: Evidence From Chávez Misiones", Latin American Politics and Society, Vol.49 (No.4) (Winter 2007).

Petras, James and Henry Veltmeyer, Social Movement and State Power: Argentina, Brazil, Bolivia, Ecuador (London: Pluto Press, 2005).

Raby, D. L., Democracy and Revolution: Latin America and Socialism Today (London: Pluto Press, 2006).

Roberts, Kenneth M., "Social Correlates of Party System Demise and Populist Resurgence in Venezuela", Latin American Politics and Society, Vol.45, (No.3) (Fall 2003).

Trinkunas, Harold A., "The Military: From Marginalization to Center Stage" dalam Jennifer L. McCoy and David J. Myers (Eds), The Unravelling of Representative Democracy in Venezuela (Baltimore: The Johns Hopkins University Press, 2006) Zúquete, José Pedro, "The Missionary Politics of Hugo Chávez", Latin America Politics and Society, Vol.50 (NO.1) (Spring 2008). 